International Journal of Oceanography and Hydrobiology Volume 50, No. 2, June 2021

\title{
Effects of copper and cadmium on physiology and antifouling defense of the marine macroalga Ulva reticulata
}

by

\author{
Wejdan Ahmed Al-Khaldi, \\ Lafi Al Solami, \\ Sathianeson Satheesh*
}

\section{DOI: 10.2478/oandhs-2021-0017 \\ Category: Original research paper \\ Received: October 2, 2020 \\ Accepted: December 15, 2020}

\section{Department of Marine Biology, Faculty of Marine Sciences, King Abdulaziz University, Jeddah, Jeddah Saudi Arabia}

* Corresponding author: *satheesh_s2005@yahoo.co.in; ssathianeson@kau.edu.sa

\begin{abstract}
Heavy metals are major stressors for benthic macroalgal communities in marine ecosystems. In this study, the effects of copper and cadmium on some physiological parameters along with antifouling defense of the marine macroalga Ulva reticulata were assessed under laboratory conditions. Macroalgal samples were treated with three concentrations $\left(1 \mathrm{mg} \mathrm{l}^{-1}, 3 \mathrm{mg} \mathrm{l}^{-1}\right.$ and $5 \mathrm{mg} \mathrm{l}^{-1}$ ) of copper and cadmium for 2 and 7 days. After treatment, algal samples were analyzed for chlorophyll- $a$, carotenoid, total polyphenol and total antioxidant capacity. Also, algal extracts were tested against biofilm-forming bacteria strains to understand differences in antifouling activity. The results indicated that exposure of $U$. reticulata to copper and cadmium, on the one hand, induced protective mechanisms such as total phenol production and antioxidant capacity against metal stress and, on the other hand, reduced photosynthesis. While the extract obtained from control algal samples showed a strong inhibitory effect on the growth of biofilm-forming bacteria, treatment with heavy metals resulted in reduced antibiofilm activity. In general, the results revealed that exposure of macroalgae to heavy metals can affect antifouling defense traits in addition to changes in photosynthetic pigment content.
\end{abstract}

Key words: marine pollution, heavy metals, antifouling, antioxidant activity, antibiofilm, seaweed, Ulva, Red Sea 


\section{Introduction}

Macroalgal communities play a key role in coastal ecosystem functioning by acting as a primary producer and providing refuge for a number of organisms (Wang et al. 2014; Schiel \& Foster 2015). Marine pollution is considered to be one of the factors contributing to the decline of macroalgal populations in coastal ecosystems (Martins et al. 2012; Scherner et al. 2013). Among the pollutants, heavy metals have a significant impact on macroalgal communities. Due to the sensitivity of macroalgae to anthropogenic pressure and environmental factors, these systems are used as a valuable indicator to assess the health of coastal ecosystems (Mannino \& Micheli 2020). The effects of metals on algae have been previously studied due to the ability of these organisms to uptake metal ions and accumulate them in their tissues (Flouty \& Estephane 2012). Further, heavy metal accumulation in macroalgae has both direct and indirect effects on organisms at higher trophic levels (Contreras-Porcia et al. 2017).

Once accumulated, metals can cause physiological damage depending on the sensitivity of the organisms (Polo et al. 2014; Costa et al. 2016). Higher concentration of metals has severe effects on the growth and metabolism of many algae species (Ismail \& Ismail 2017). In brief, exposure of algae to higher concentration of heavy metals resulted in an increase in lipoperoxides and a decrease in antioxidant enzymes, reduction in reactive oxygen species (ROS) production, protein content, free amino acids and carbohydrates (Contreras et al. 2009; Huang et al. 2010; Yadav 2010; Foyer \& Noctor 2011). Moreover, heavy metals can also reduce the content of photosynthetic pigments, the growth and cause cell damage (Xia et al. 2004; Saleh 2015; Zhu et al. 2017).

In addition to physiological effects, heavy metals affect the chemical defense properties of marine macroalgal communities (Lurling 2012; Warneke \& Long 2015). Macroalgae are characterized by a strong chemical defense mechanism against herbivores and colonizing marine organisms (Paul et al. 2001; Sudatti et al. 2018). Epibiosis or biofouling on surfaces can have detrimental effects on marine macroalgae, mainly reduction in growth and reproduction, biomass loss, depletion of nutrients and tissue damage (Jormalainen \& Honkanen, 2008; Da Gama et al. 2014). To reduce fouling, most macroalgae are equipped with antifouling defense mechanisms against both microand macrofoulers (da Gama et al. 2008).The antifouling defense is mainly achieved through the production of secondary metabolites. Many bioactive metabolites play an important role in macroalgal defense against fouling organisms and herbivores (Paul et al. 2006; Pereira \& Da Gama 2008). In addition, pollutants can interfere with the production and composition of bioactive metabolites in marine algae (Pinto et al. 2011; Gressler et al. 2011). Any change in the biosynthesis of secondary metabolites can reduce the defense properties of macroalgae against fouling organisms and herbivores. Further, algae with fouling organisms on their surface are more attractive to herbivores ( $\mathrm{Da}$ Gama et al. 2008).

While the physiological effects of metal pollution on macroalgal communities have been studied in detail (Huang et al. 2010; Jiang et al. 2013; Saleh 2015; Costa et al. 2016), the effects of metals on the antifouling defense of marine macroalgae have received little attention. Most of the previous studies have focused on the effects on antioxidant enzymes and total phenolic content (Toth \& Pavia 2000; Tzure-Meng et al. 2009; Costa et al. 2016). Therefore, in this study, the effects of two selected metals, copper and cadmium, on macroalgae physiology and antifouling defense were assessed using Ulva reticulata as a model green alga. The selection of these two heavy metals was based on previous studies that reported that copper and cadmium can affect gametophyte development and distribution of cellular components in various macroalgae species (Contreras et al. 2007; Leal et al. 2018). The results observed in this study will enhance our knowledge about the effects of metal pollutants on antifouling defense of macroalgae, which is considered one of the important adaptations providing resistance to herbivores and unwanted colonization.

\section{Materials and methods}

\subsection{Collection of macroalga}

The green macroalga Ulva reticulata Forsskal 1775 was collected from the Obhur Creek $\left(21^{\circ} 42^{\prime} 33.52^{\prime \prime} \mathrm{N}\right.$; $\left.39^{\circ} 5^{\prime} 45.71^{\prime \prime} \mathrm{E}\right)$, the central Red Sea, Saudi Arabia. Salinity, temperature and $\mathrm{pH}$ of the creek water at the time of sampling were $39 \mathrm{PSU}, 25.5^{\circ} \mathrm{C}$ and 8.3 , respectively. These parameters were measured in situ using a portable multiparameter water quality monitor (Hanna). Many previous studies described hydrographic and environmental properties of the Obhur Creek waters (Alsaafani et al. 2017; Salama et al. 2018). The collected algal samples were brought to the laboratory in a bucket with seawater. In the laboratory, they were initially rinsed with filtered (Millipore, $0.47 \mu \mathrm{m}$ ) seawater to eliminate the epifauna and debris. Ulva reticulata was identified based on 
morphological characters according to the available identification keys (Dhargalkar \& Kavlekar 2004; Brodie et al. 2007). Samples were kept in glass tanks containing filtered seawater. The tanks were kept at $25^{\circ} \mathrm{C}$ under $80 \mu \mathrm{mol} \mathrm{E} \mathrm{m}{ }^{-2} \mathrm{~s}^{-1}$ illumination (14 h light/ $10 \mathrm{~h}$ dark cycle) with gentle aeration. Salinity and $\mathrm{pH}$ of seawater in the tank during the experiment were 38 PSU and 8.3, respectively. Salinity and $\mathrm{pH}$ of water were measured using a refractometer and $\mathrm{pH}$ meter (Hanna), respectively. Samples were acclimatized under laboratory conditions for 5 days prior to experiments.

\subsection{Heavy metals and stock toxicant solution preparation}

Two heavy metals, copper $(\mathrm{Cu})$ in the form of copper sulfate $\left(\mathrm{CuSO}_{4}\right)$ and cadmium (Cd) as cadmium chloride $\left(\mathrm{CdCl}_{2}\right)$, were used as toxicants to study their effects on the alga $U$. reticulata. To prepare a stock solution, $5 \mathrm{~g}$ of a metal compound was dissolved in $100 \mathrm{ml}$ distilled water in dark bottles. Fresh stock solution was prepared for each day of the experiment.

\subsection{Experimental design}

The acclimatized macroalgal samples (100 g) were transferred to small glass tanks (5 I) with filtered seawater. Three different toxicant concentrations, $1 \mathrm{mg}$ $\mathrm{I}^{-1}, 3 \mathrm{mg} \mathrm{l}^{-1}$ and $5 \mathrm{mg} \mathrm{l}^{-1}$, were used to study the effects. The toxicant was added from the stock solution prepared for each metal compound. The experiment was conducted for 7 days in replicates $(n=3$, three independent experiments were conducted for each metal). Macroalgae samples kept in the tank without the addition of any of the metal solutions were used as a reference. Seawater in the tanks was changed on each day of the experiment and a fresh metal solution was added. Samples (about $20 \mathrm{~g}$ ) were collected from each tank after 2 and 7 days of exposure to metals. One portion of the collected samples was processed immediately for pigment analysis (Chlorophyll- $a$ and carotenoids). The other portion of an algal sample was dried under shade for one week, powdered and used for the analysis of other parameters. Ethanolic extract of dried algal powder was prepared with $2.5 \mathrm{~g}$ of dried algae samples with $10 \mathrm{ml}$ of ethanol. The mixture was kept in a shaker for 3 days and centrifuged at 3000 rpm for $15 \mathrm{~min}$ at $4^{\circ} \mathrm{C}$. The resulting crude extract was filtered and used for the experiments.

\subsection{Chlorophyll- $a$ and carotenoid content analysis}

Macroalgal samples $(500 \mathrm{mg}$ of fresh algal tissue from each sample) were macerated with $10 \mathrm{ml}$ of acetone in a pestle and mortar under dark conditions. The homogenate was centrifuged at $3000 \mathrm{rpm}$ for $15 \mathrm{~min}$ at $4^{\circ} \mathrm{C}$. The supernatant was collected in test tubes, which were covered with aluminum foil and the absorbance at $470 \mathrm{~nm}, 647 \mathrm{~nm}$ and $664 \mathrm{~nm}$ was measured immediately in a UV-Vis spectrophotometer. The content of chlorophyll- $a(\mathrm{Chl}-a)$ and carotenoid was calculated using the formulae provided in the related literature (Jeffrey \& Humphrey 1975; Torres et al. 2014).

\subsection{Analysis of total phenolic content}

The total phenolic content in algal samples was measured by the method described by Singleton \& Rossi (1965) with some modifications. Distilled water $(1.58 \mathrm{ml})$ and the Folin-Ciocalteu reagent $(100 \mu \mathrm{l})$ were added to the macroalgal extract $(20 \mu \mathrm{l})$. The mixture was then allowed to settle for $5 \mathrm{~min}$ at room temperature. Sodium carbonate solution $(300 \mu \mathrm{l})$ was then added and agitated carefully for $10 \mathrm{~min}$. The mixture was kept for $2 \mathrm{~h}$ under dark conditions at $20^{\circ} \mathrm{C}$. The optical density of the mixture was measured at 765 $\mathrm{nm}$ using a spectrophotometer. The total polyphenolic content in the analyzed samples was determined from the absorbance of the standard (gallic acid) and the values obtained were presented as $\mathrm{mg}$ gallic acid equivalents $\mathrm{g}^{-1}$ of algal dry weight.

\subsection{Total Antioxidant capacity assay}

The antioxidant capacity of algal samples was determined by the method described by Prieto et al. (1999). In brief, sulfuric acid (0.6 M), sodium phosphate $(28 \mathrm{mM})$ and ammonium molybdate $(4 \mathrm{mM})$ were mixed to prepare a total antioxidant capacity (TAC) reagent. The TAC $(3 \mathrm{ml})$ was added to $50 \mu \mathrm{l}$ of algal extracts and kept at $95^{\circ} \mathrm{C}$ for $90 \mathrm{~min}$ in a water bath. After removal from the water bath, the TAC and algal extract mixture was cooled for $10 \mathrm{~min}$ at room temperature. The optical density (OD) was then measured at $695 \mathrm{~nm}$ in a spectrophotometer using ethanol as blank. The OD of ascorbic acid was used as a standard to calculate the total antioxidant capacity, and the values obtained were presented as equivalents of ascorbic acid $\left(\mu \mathrm{g} \mathrm{ml}^{-1}\right)$.

\subsection{Bacterial growth inhibition assay}

This experiment was conducted to understand the variation in antibacterial activity of $U$. reticulata samples after being treated with heavy metals. Two biofilm-forming bacteria strains, Pseudomonas shioyasakiensis (NCBI: KY224086) and Vibrio harveyi 
(NCBI: KY266820), maintained in our laboratory, were used as target organisms for a growth inhibition assay. These bacteria strains were isolated from the artificial material submerged in the Obhur Creek (Balqadi et al. 2018). An overnight grown bacteria culture (marine broth, Difco) was used for the experiment. The bacterial culture $(3 \mathrm{ml})$ was collected into test tubes and $30 \mu \mathrm{l}$ algal extracts were added. Two types of controls, one with $30 \mu \mathrm{l}$ of ethanol and another without solvent or algal extracts (only bacteria culture) were maintained. The OD of the culture was measured at $570 \mathrm{~nm}$ in a spectrophotometer immediately after the addition of the extracts. The test tubes were cotton plugged and kept in an incubator at $30^{\circ} \mathrm{C}$ for $24 \mathrm{~h}$. After that, the final OD was measured and the percentage of bacteria growth inhibition by the extracts was calculated using the following formula:

Growth Rate $(\%)=\frac{\text { Final } O D \text { value }- \text { Initial } O D \text { value }}{\text { Initial } O D \text { value }} \times 100$

\subsection{Metal accumulation in algal samples}

The content of heavy copper and cadmium in algal samples treated with different concentrations of solutions of respective metals was analyzed by the method described in Topcuoglu et al. (2003). The dried algal samples $(5 \mathrm{~g})$ were placed in Teflon vessels and digested by adding $\mathrm{H}_{2} \mathrm{SO}_{4}(5 \mathrm{ml})$. The samples were then heated on a hot plate at $70-80^{\circ} \mathrm{C}$ for $15 \mathrm{~min}$. The sample was then allowed to cool at room temperature and $2 \mathrm{ml}$ of concentrated $\mathrm{HNO}_{3}$ was added slowly. This mixture was again heated for $30 \mathrm{~min}$ and allowed to cool. After cooling, $15 \mathrm{ml}$ of $\mathrm{H}_{2} \mathrm{O}_{2}$ was added and heated for $2 \mathrm{~h}$ at $150^{\circ} \mathrm{C}$. Finally, the solution was diluted to $100 \mathrm{ml}$ with $2 \%$ concentrated $\mathrm{HNO}_{3}$ in a volumetric flask. Blank samples were prepared using the same protocol without algal samples. The content of copper and cadmium in the samples was analyzed (minimum detection limit: $0.001 \mu \mathrm{g} \mathrm{g}^{-1}$ ) by inductively coupled plasma mass spectrometry (ICP-MS). The obtained values were presented as $\mu \mathrm{g} \mathrm{g}^{-1}$ dry weight of an algal sample.

\subsection{Statistical analysis}

Data were analyzed for differences in different physiological parameters and bacterial growth inhibitory activity between control and metal-treated algal samples using three-way ANOVA. Concentration, treatment duration and metals were used as factors in
ANOVA. Tukey's post-hoc test was used when ANOVA results showed significant differences between algal samples treated with different concentrations of metals. Two-way ANOVA was also used to examine the differences in bioaccumulation of copper and cadmium in algal samples. Treatment concentration and exposure duration were used as factors in two-way ANOVA. Further, simple correlation analysis was performed to determine the relationship between bacterial growth, bioaccumulation of metals and different physiological parameters. All statistical analyses were carried out using STATISTICA and $p<0.05$ was considered significant.

\section{Results}

\subsection{Chlorophyll content}

Chl- $a$ content in a control algal sample was 200.31 $\mu \mathrm{g} \mathrm{g^{-1 }}$ after 2 days and $133.41 \mu \mathrm{g} \mathrm{g}{ }^{-1}$ after 7 days (Fig. 1). Samples treated with copper and cadmium showed a decrease in Chl- $a$ after 2 and 7 days of exposure. A concentration-dependent decrease was observed in samples treated with both copper and cadmium (not significant, three-way ANOVA; Table 1). The Chl- $a$ content in samples treated with $1 \mathrm{mg} \mathrm{l}^{-1}$ of Cu was $165.8 \mu \mathrm{g} \mathrm{g}^{-1}$ after 2 days and $143.72 \mu \mathrm{g} \mathrm{g}^{-1}$ after 7 days. Similarly, the Chl- $a$ content in algal samples treated with $3 \mathrm{mg} \mathrm{l}^{-1}$ of $\mathrm{Cu}$ showed a decrease (159.88 $\mu \mathrm{g} \mathrm{g}^{-1}$ ) after 2 days and 7 days $\left(99.75 \mu \mathrm{g} \mathrm{g}^{-1}\right)$. The lowest Chl- $a$ content $\left(79.93 \mu \mathrm{g} \mathrm{g}^{-1}\right)$ was determined in $U$. reticulata samples treated with $5 \mathrm{mg} \mathrm{l}^{-1}$ of copper for 7 days (Fig. 1).

\subsection{Carotenoid content}

The carotenoid content in the control algal sample was $88.05 \mu \mathrm{g} \mathrm{g}^{-1}$ after 2 days and $62.04 \mu \mathrm{g} \mathrm{g}^{-1}$ after 7 days (Fig. 1). Algal samples treated with copper and cadmium varied in carotenoid content. While a gradual decrease in carotenoid content with treatment concentration was observed in samples treated with copper for 2 and 7 days. A slight increase in carotenoid levels was observed in samples treated with $1 \mathrm{mg}$ $\mathrm{I}^{-1}$ and $3 \mathrm{mg} \mathrm{I}^{-1}$ of cadmium for 7 days. The lowest carotenoid content $\left(27.17 \mu \mathrm{g} \mathrm{g}^{-1}\right)$ was measured in algal samples treated with $5 \mathrm{mg} \mathrm{l}^{-1}$ of cadmium for 7 days (Fig. 1). Three-way ANOVA results indicated that the differences in carotenoid content due to copper and cadmium treatments were not significant (Table 1). 
a

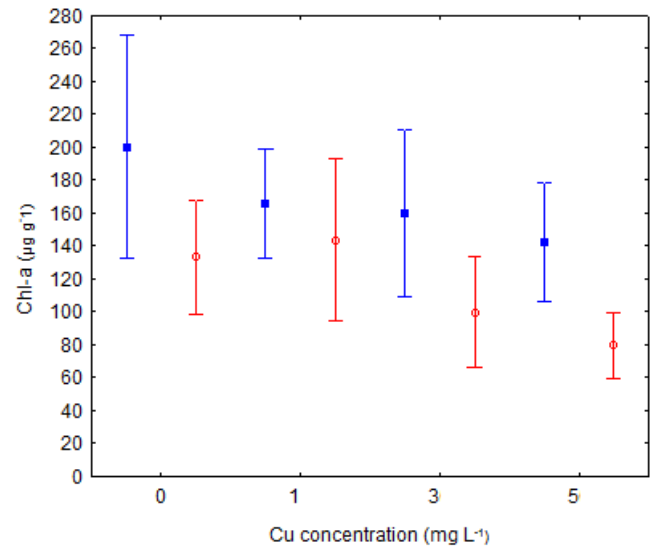

C

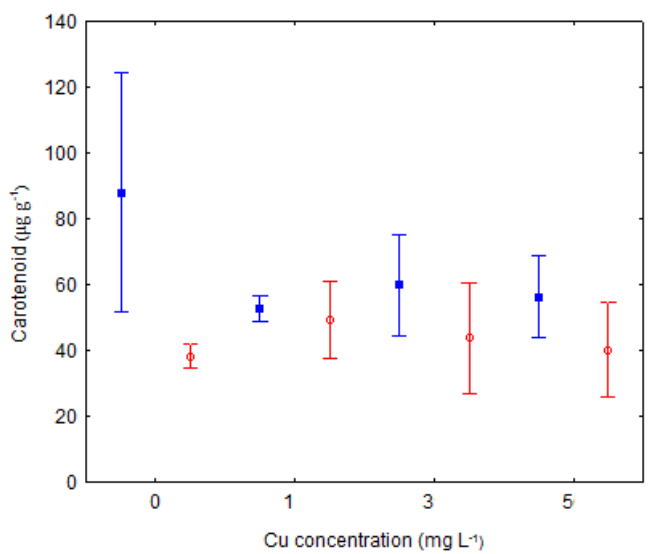

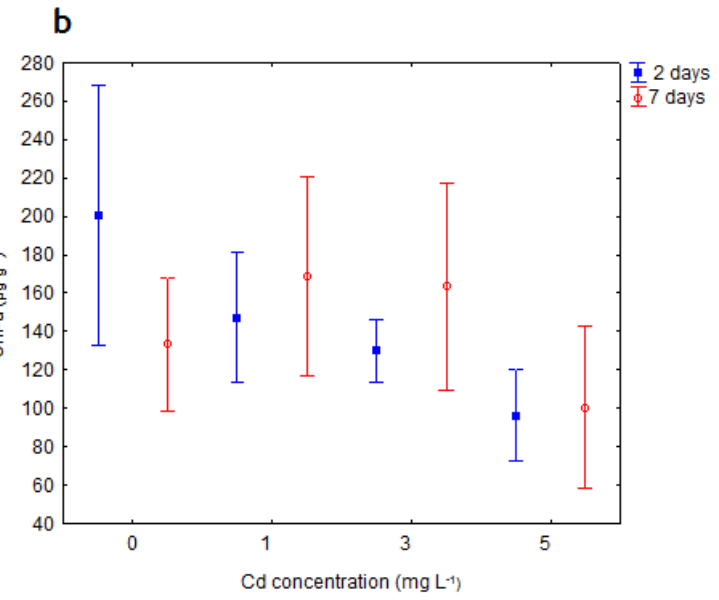

d

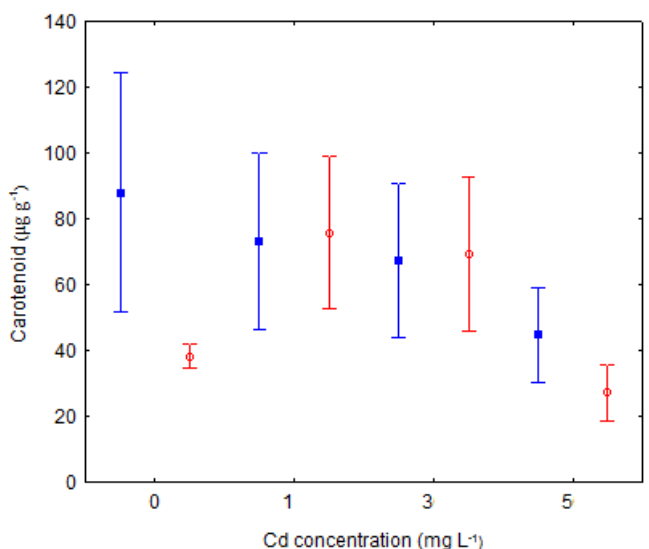

\section{Figure 1}

Changes in chlorophyll- $a$ and carotenoid content (mean $\pm \mathrm{SE}, \mathrm{n}=3$ ) in the macroalga U. reticulata treated with heavy metals for 2 and 7 days. a) Chlorophyll-a content in algal samples treated with copper. b) Chlorophyll-a content in algal samples treated with cadmium. c) Carotenoid content in algal samples treated with copper. d) Carotenoid content in algal samples treated with cadmium

Table 1

Three-way ANOVA results showing the variations in antifouling defense and physiological parameters of the macroalga $U$. reticulata treated with copper and cadmium. Treatment concentration $\left(0,1,3\right.$ and $\left.5 \mathrm{mg} \mathrm{l}^{-1}\right)$, duration ( 2 and 7 days) and metals (copper and cadmium) were used as factors for ANOVA ( $p<0.05=$ significant).

\begin{tabular}{|c|c|c|c|c|c|c|c|c|c|c|c|c|c|}
\hline \multirow[t]{2}{*}{ Factors } & \multirow[t]{2}{*}{ df } & \multicolumn{2}{|c|}{ P. shioyasakiensis } & \multicolumn{2}{|c|}{ V. harveyi } & \multicolumn{2}{|c|}{ Chl- $a$} & \multicolumn{2}{|c|}{ Carotenoids } & \multicolumn{2}{|c|}{ Phenol } & \multicolumn{2}{|c|}{$\begin{array}{c}\text { Total antioxidant } \\
\text { capacity }\end{array}$} \\
\hline & & $\mathrm{F}$ & $p$ & $\mathrm{~F}$ & $p$ & $\mathrm{~F}$ & $p$ & $F$ & $p$ & $\mathrm{~F}$ & $p$ & $F$ & $p$ \\
\hline Concentration & 3 & 18.68 & 0.000 & 15.15 & 0.000 & 1.57 & 0.213 & 1.02 & 0.395 & 1.40 & 0.258 & 89.65 & 0.000 \\
\hline Days & 1 & 40.29 & 0.000 & 0.91 & 0.345 & 1.61 & 0.213 & 3.48 & 0.070 & 18.08 & 0.000 & 133.51 & 0.000 \\
\hline Metals & 1 & 0.15 & 0.695 & 1.98 & 0.168 & 0.00 & 0.934 & 0.48 & 0.490 & 9.10 & 0.004 & 16.22 & 0.000 \\
\hline Concentration $\mathrm{x}$ Days & 3 & 8.08 & 0.000 & 1.42 & 0.253 & 0.44 & 0.723 & 1.22 & 0.317 & 2.07 & 0.123 & 40.36 & 0.000 \\
\hline Concentration $\mathrm{x}$ Metals & 3 & 0.52 & 0.666 & 0.77 & 0.517 & 0.08 & 0.970 & 0.66 & 0.582 & 1.99 & 0.134 & 34.77 & 0.000 \\
\hline Days x Metals & 1 & 7.98 & 0.008 & 2.28 & 0.140 & 1.38 & 0.248 & 0.08 & 0.776 & 5.68 & 0.023 & 120.35 & 0.000 \\
\hline Concentration $\mathrm{x}$ Days $\mathrm{x}$ Metals & 3 & 4.98 & 0.006 & 3.03 & 0.043 & 0.20 & 0.889 & 0.04 & 0.984 & 1.25 & 0.306 & 29.64 & 0.000 \\
\hline Error & 32 & & & & & & & & & & & & \\
\hline Total & 47 & & & & & & & & & & & & \\
\hline
\end{tabular}




\subsection{Total phenolic content}

The control algal sample showed a total phenolic content of $3.02 \mathrm{mg} \mathrm{GAE} \mathrm{g}^{-1}$ after 2 days and $1.86 \mathrm{mg}$ GAE g-1 after 7 days. Samples treated with $1 \mathrm{mg} \mathrm{l}^{-1}$ of copper showed a decrease in phenolic content after 2 days (2.204 $\mathrm{mg} \mathrm{GAE} \mathrm{g}^{-1}$ ) and 7 days (1.103 $\mathrm{mg} \mathrm{GAE} \mathrm{g}^{-1}$ ). Samples treated with $3 \mathrm{mg} \mathrm{l}^{-1}$ and $5 \mathrm{mg} \mathrm{l}^{-1}$ of copper also showed a decrease in phenolic content after 2 and 7 days of treatment (Fig. 2). A very low phenolic content of $0.778 \mathrm{mg} \mathrm{GAE} \mathrm{g}^{-1}$ was observed after 7 days of a copper treatment at a dose of $3 \mathrm{mg} \mathrm{l}^{-1}$. Contrary to the copper treatment, samples treated with cadmium showed an increase in total phenolic content after 2 days of exposure (Fig. 2). In algal samples exposed to cadmium for 7 days, a decrease in total phenolic content was observed in samples treated with $3 \mathrm{mg} \mathrm{l}^{-1}$ and $5 \mathrm{mg} \mathrm{l}^{-1}$ (1.48 and $0.98 \mathrm{mg} \mathrm{GAE} \mathrm{g}^{-1}$, respectively). Further, ANOVA results showed significant differences in the total phenolic content in algal samples depending on the treatment duration (Table 1). Changes in the phenol content in algal samples also showed significant differences between $\mathrm{Cu}$ and $\mathrm{Cd}$ treatments (Table 1).

\subsection{Total antioxidant capacity assay}

$U$. reticulata samples (control) revealed the antioxidant capacity of 330.87 and $262.64 \mu \mathrm{g} \mathrm{ml}^{-1}$ after 2 and 7 days under laboratory conditions. However, samples treated with copper and cadmium showed higher levels (significant variation between the metals;
Table 1) compared to the control after both 2 and 7 days of exposure (Fig. 3). The antioxidant capacity was remarkably high in samples observed after 2 days (706.5 $\mu \mathrm{g} \mathrm{ml}^{-1}$ for copper-treated samples; 1696.65 $\mu \mathrm{g} \mathrm{ml^{-1 }}$ for cadmium-treated samples). In general, a concentration-dependent increase in antioxidant capacity was observed in samples treated for 2 days with both copper and cadmium. The highest antioxidant capacity of $1696.65 \mathrm{\mu g} \mathrm{ml}^{-1}$ was observed in the extract of algal samples treated with $5 \mathrm{mg} \mathrm{l}^{-1}$ of cadmium for 2 days. Three-way ANOVA results indicated a significant variation in antioxidant capacity as a function of metal concentration and exposure duration (Table 1). Further, significant variations were observed for all interactions between the factors used in ANOVA. While the antioxidant capacity for all concentrations of copper treated samples differed significantly from the control, an algal sample treated with $1 \mathrm{mg} \mathrm{I}^{-1}$ of cadmium showed no significant difference from the control (Table 2).

\subsection{Bacteria growth inhibition assay}

The extract obtained from control algal samples showed a strong growth inhibitory effect on the bacterium $P$. shioyasakiensis. However, algal samples treated with different concentrations of copper and cadmium for 2 days exhibited a relatively weak growth inhibitory effect on P. shioyasakiensis (Fig. 4). Further, extracts obtained from algae treated with $1 \mathrm{mg} \mathrm{l}^{-1}$ of copper and cadmium for 2 days showed very low growth inhibitory activity. Algal samples treated with
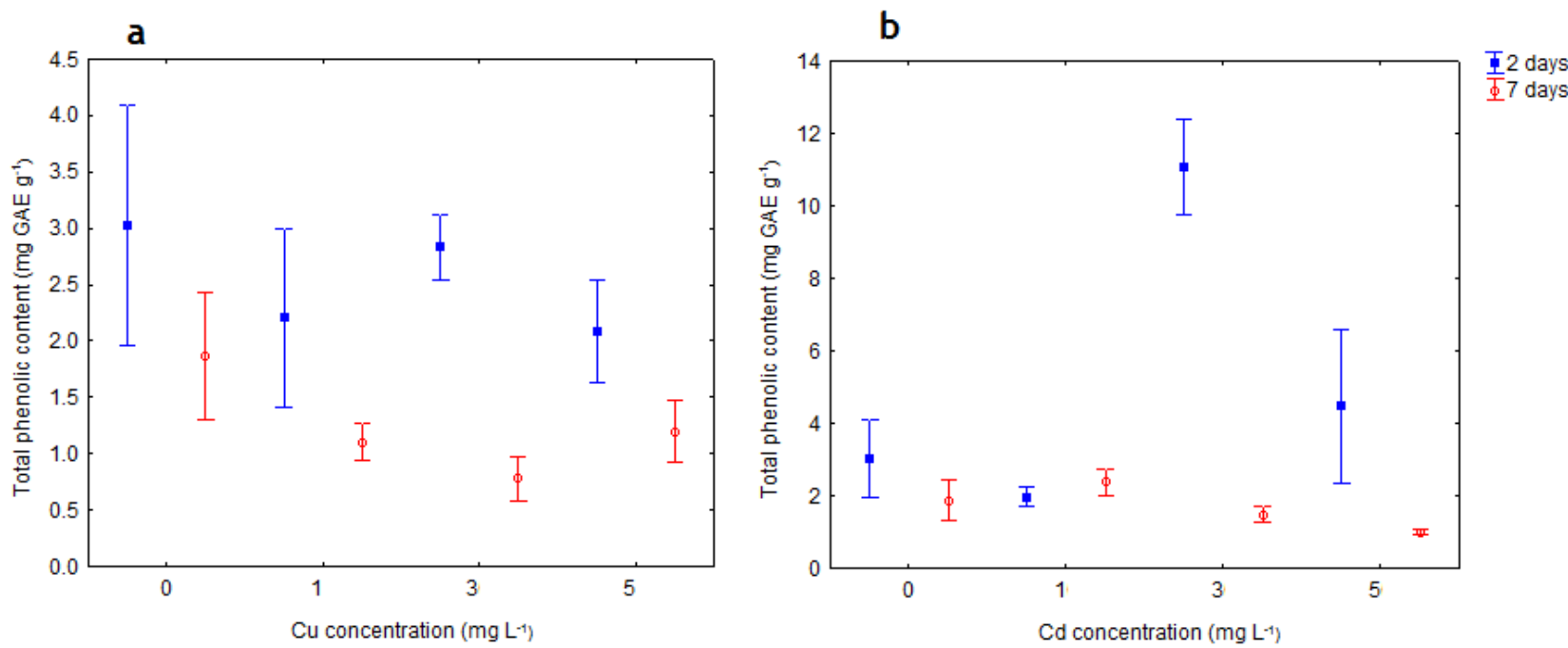

Figure 2

Effects of heavy metal treatment on total phenol content (mean $\pm \mathrm{SE}, \mathrm{n}=3$ ) in the macroalga U. reticulata. a) Total phenol content in algal samples treated with copper. b) Total phenol content in algal samples treated with cadmium. 

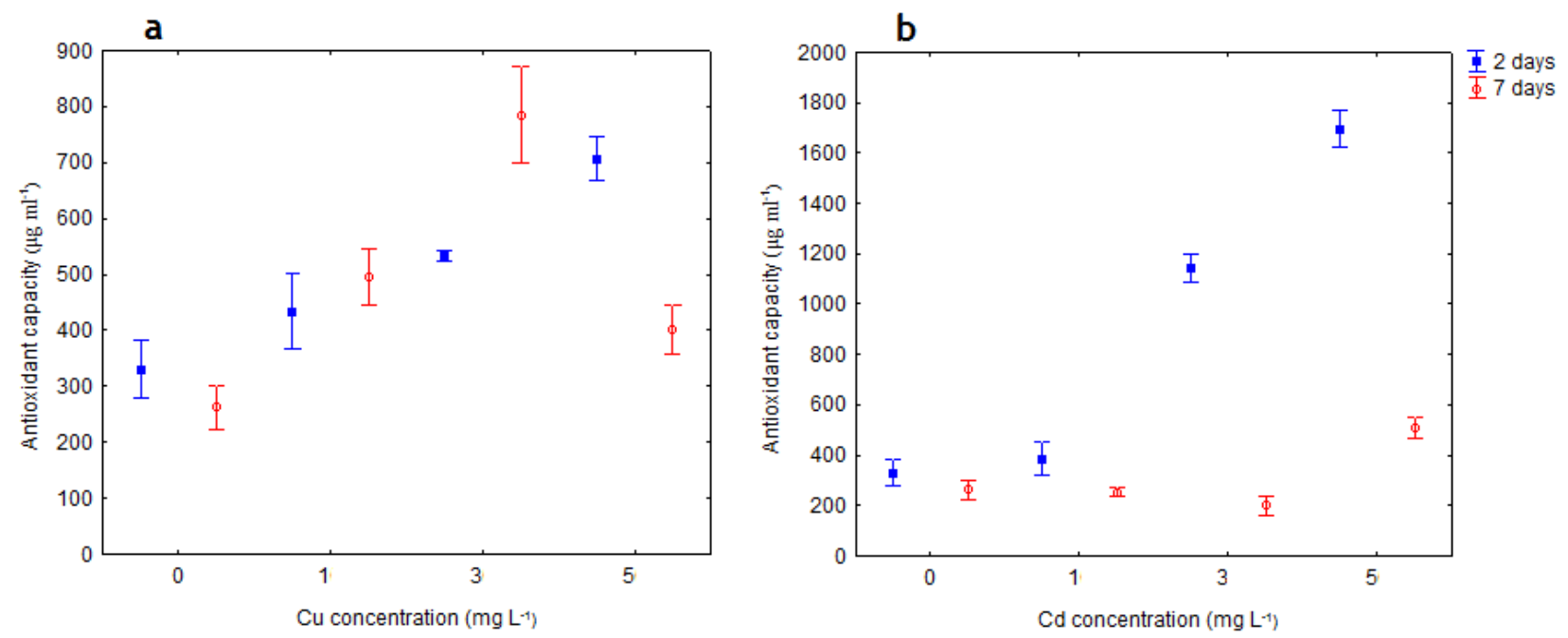

\section{Figure 3}

Changes in total antioxidant capacity (mean $\pm S E, n=3$ ) in algal samples treated with copper and cadmium for 2 and 7 days. a) Total antioxidant capacity of algal samples treated with copper. b) Total antioxidant capacity of algal samples treated with cadmium.

Table 2

Post-hoc Tukey HSD test results for the effects of different concentrations of copper and cadmium on the macroalga U. reticulata $(p<0.05=$ significant $)$

\begin{tabular}{|c|c|c|c|c|c|c|c|}
\hline \multirow[b]{2}{*}{ Factor 1} & \multirow[b]{2}{*}{ Factor 2} & \multicolumn{2}{|c|}{ Total antioxidant activity } & \multicolumn{2}{|c|}{ Bacterial growth $P$. shioyasakiensis } & \multicolumn{2}{|c|}{ Bacterial growth V. harveyi } \\
\hline & & $\begin{array}{c}\text { Cu-treated } \\
\text { samples }\end{array}$ & $\begin{array}{l}\text { Cd-treated } \\
\text { samples }\end{array}$ & $\begin{array}{c}\text { Cu-treated algal } \\
\text { extracts }\end{array}$ & $\begin{array}{l}\text { Cd-treated algal } \\
\text { extracts }\end{array}$ & $\begin{array}{c}\text { Cu-treated algal } \\
\text { extracts }\end{array}$ & $\begin{array}{c}\text { Cd-treated algal } \\
\text { extracts }\end{array}$ \\
\hline \multirow{3}{*}{ Control } & $1 \mathrm{mg} \mathrm{l}^{-1}$ & 0.049 & 0.966 & 0.028 & 0.001 & 0.001 & 0.000 \\
\hline & $3 \mathrm{mg} \mathrm{l}^{-1}$ & 0.000 & 0.000 & 0.020 & 0.007 & 0.001 & 0.005 \\
\hline & $5 \mathrm{mg} \mathrm{l}^{-1}$ & 0.000 & 0.000 & 0.000 & 0.001 & 0.075 & 0.001 \\
\hline \multirow{2}{*}{$1 \mathrm{mg} \mathrm{l}^{-1}$} & $3 \mathrm{mg} \mathrm{l}^{-1}$ & 0.013 & 0.000 & 1.000 & 0.999 & 1.000 & 0.981 \\
\hline & $5 \mathrm{mg} \mathrm{l}^{-1}$ & 0.668 & 0.000 & 0.669 & 1.000 & 0.811 & 0.999 \\
\hline $3 \mathrm{mg} \mathrm{l}^{-1}$ & $5 \mathrm{mg} \mathrm{l}^{-1}$ & 0.473 & 0.000 & 0.755 & 0.999 & 0.789 & 0.999 \\
\hline
\end{tabular}

copper and cadmium for 7 days also showed lower growth inhibitory activity (except the extract obtained from samples treated with $5 \mathrm{mg} \mathrm{^{-1 }}$ of cadmium). Algal extracts obtained from samples treated with copper and cadmium exhibited a weak growth inhibitory effect on the bacterium $V$. harveyi (Fig. 4). A concentration-dependent reduction in bacterial growth inhibitory activity was observed for extracts obtained from samples treated with cadmium for 2 days. The growth inhibitory activity of algal samples treated with copper and cadmium was very low except for the extract obtained from samples treated with copper at $5 \mathrm{mg} \mathrm{l}^{-1}$ for 2 days.

The ANOVA results indicated a significant variation in bacterial growth inhibitory activity of algal extracts depending on the concentration of metals and days of exposure against $P$. shioyasakiensis (Table 1 ). On the other hand, a significant difference was observed between metal concentration and growth percentage of $V$. harveyi (Table 1). Tukey's post-hoc test revealed significant variation in bacterial growth inhibitory activity between algal samples treated with different concentrations of metals and control samples (Table 2). The growth rate of $P$. shioyasakiensis also showed a significant negative correlation with the bioaccumulation of copper in algal samples (Table 3), but $V$. harveyi showed a significant positive correlation. A positive correlation was determined between the antioxidant activity and the growth rate of P. shioyasakiensis (Table 3).

\subsection{Metal accumulation in $U$. reticulata}

The content of copper and cadmium in algal samples treated with different concentrations of copper sulfate and cadmium chloride is presented 

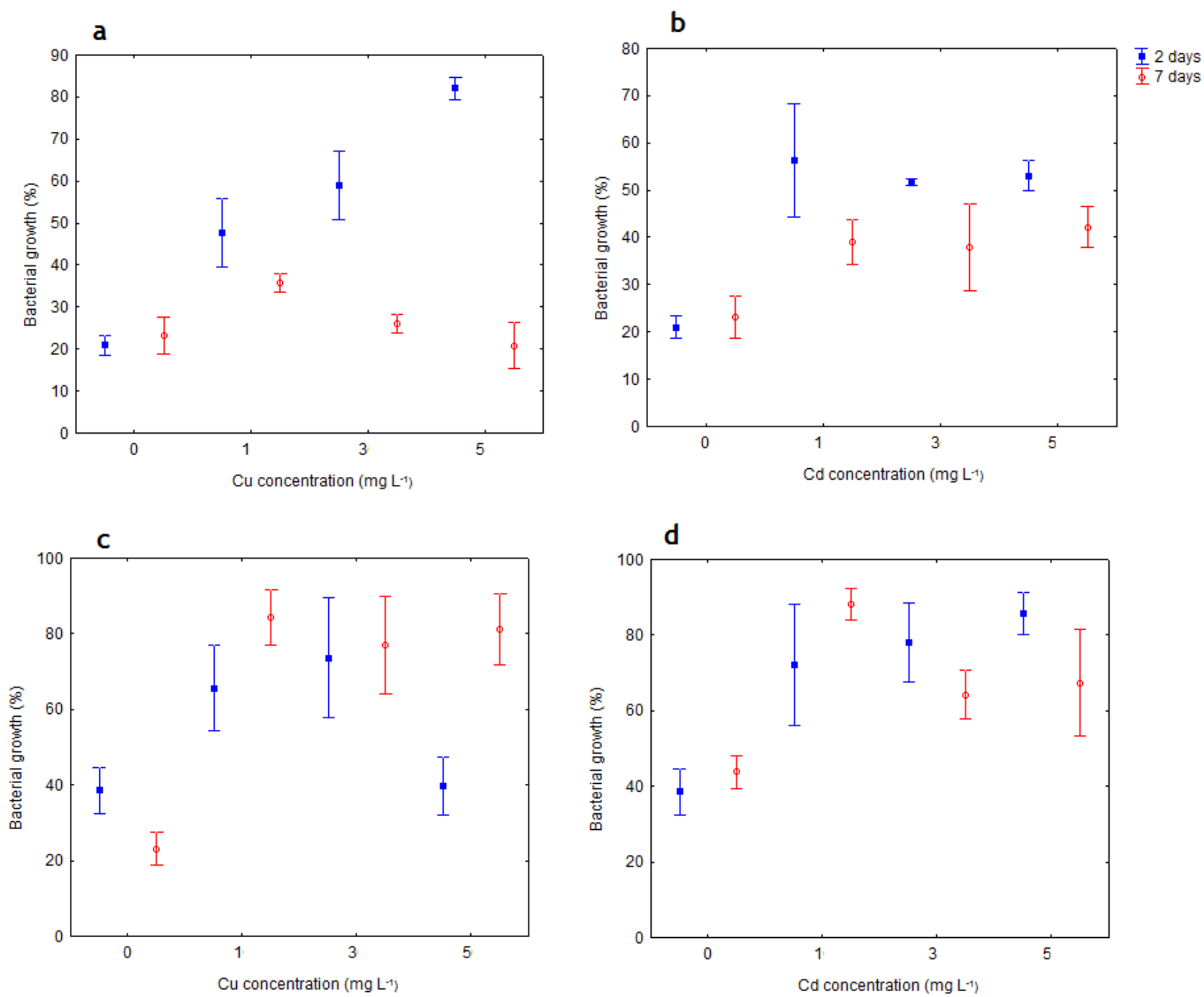

\section{Figure 4}

Effects of heavy metal treatment on antifouling defense of the marine macroalga U. reticulata. Antifouling activity of algal extracts was tested against two biofilm-forming bacteria. a) Growth inhibitory activity of copper-treated samples against $P$. shioyasakiensis; b) Growth inhibitory activity of cadmium-treated samples against $P$. shioyasakiensis; c) Growth inhibitory activity of the extract from copper-treated algal samples against V. harveyi; d) Growth inhibitory activity of the extract from cadmium-treated algal samples against $V$. harveyi. Error bars indicate SE of mean values $(n=3)$.

Table 3

Correlation between bacterial growth and physiological parameters of the macroalga $U$. reticulate $(p<0.05=$ significant). Bioaccumulation of copper and cadmium was also used in correlation analysis.

\begin{tabular}{|c|c|c|c|c|c|c|}
\hline Copper-treated samples & P. shioyasakiensis & V. harveyi & Cadmium-treated samples & P. shioyasakiensis & V. harveyi \\
\hline Antioxidant capacity & 0.39 & 0.31 & Antioxidant capacity & $0.44^{*}$ & 0.39 \\
\hline Total phenol & 0.20 & -0.37 & Total phenol & 0.38 & 0.29 \\
\hline Chl- $a$ & 0.16 & -0.13 & Chl- $a$ & -0.05 & -0.19 \\
\hline Carotenoid & 0.05 & -0.08 & Carotenoid & 0.05 & 0.02 \\
\hline Cu accumulation & $-0.43^{*}$ & $0.43^{*}$ & Cd accumulation & -0.008 & 0.047 \\
\hline * significant & & & &
\end{tabular}


on Figure 5. In control samples, the copper content was 0.057 and $0.049 \mu \mathrm{g} \mathrm{g}^{-1}$ after 2 and 7 days under laboratory conditions. However, copper accumulation in the algal tissue was observed in samples treated with copper sulfate with a maximum of $17.71 \mu \mathrm{g} \mathrm{g}^{-1}$ (samples treated with $5 \mathrm{mg} \mathrm{l}^{-1}$ of copper for 7 days). Similarly, cadmium accumulation was observed in algal samples treated with $5 \mathrm{mg} \mathrm{l}^{-1}$ of cadmium for 7 days, with a maximum of $0.72 \mu \mathrm{g} \mathrm{g}^{-1}$. The cadmium content in control algal samples was 0.012 and $0.003 \mu \mathrm{g} \mathrm{g}^{-1}$ after 2 and 7 days. In general, a significant increase in metal content was observed in algal samples with increasing exposure duration and treatment concentrations (Table 4). The bioaccumulation level of copper in algal samples indicated a significant negative correlation with $\mathrm{Chl}-a$ and the total phenolic content in algal samples (Table 5). However, cadmium concentration in algal samples showed no significant correlation with physiological parameters.

\section{Discussion}

Heavy metal pollution is one of the major anthropogenic stressors affecting the marine environment throughout the world (Tzafriri-Milo et al. 2019). After entering the coastal waters through various sources, heavy metals accumulate in marine organisms (Saez et al. 2012; Lozano-Bilbao et al. 2019). This study showed that the macroalga $U$. reticulata can accumulate copper and cadmium from water. The accumulation level increases as the concentration of these metals in water increases. Cadmium content
Table 4

Two-way ANOVA of bioaccumulation of copper and cadmium in the macroalga $U$. reticulata. Treatment concentration and duration were used as factors $(p<0.05=$ significant $)$.

\begin{tabular}{|r|c|c|c|c|c|}
\multirow{2}{*}{ Factors } & \multirow{2}{*}{ df } & \multicolumn{2}{c|c}{$\begin{array}{c}\text { Cu } \\
\text { accumulation }\end{array}$} & \multicolumn{2}{c|}{$\begin{array}{c}\text { Cd } \\
\text { accumulation }\end{array}$} \\
\cline { 3 - 6 } & & $\mathrm{F}$ & $p$ & $\mathrm{~F}$ & $p$ \\
\hline Concentration & 3 & 58.427 & 0.000 & 35.030 & 0.000 \\
\hline Days & 1 & 229.51 & 0.000 & 68.458 & 0.000 \\
\hline Concentration x Days & 3 & 59.790 & 0.000 & 37.720 & 0.000 \\
\hline Error & 16 & & & & \\
\hline Total & 23 & & & & \\
\hline
\end{tabular}

Table 5

Correlation between metal accumulation and physiological parameters of the macroalga U. reticulata $(p<0.05=$ significant $)$.

\begin{tabular}{|c|c|c|c|c|}
$\begin{array}{c}\text { Metal } \\
\text { accumulation }\end{array}$ & Chl- $a$ & Carotenoid & $\begin{array}{c}\text { Total } \\
\text { phenol }\end{array}$ & $\begin{array}{c}\text { Antioxidant } \\
\text { capacity }\end{array}$ \\
\hline Copper & $-0.444^{*}$ & -0.264 & $-0.481^{*}$ & 0.208 \\
\hline Cadmium & -0.178 & -0.277 & -0.356 & 0.158 \\
\hline * significant & & & &
\end{tabular}

in algal samples was lower compared to copper concentrations. This may be due to the characteristic feature of Ulva species, which usually have lower cadmium concentrations (Rybak et al. 2012). In general, macroalgal communities can accumulate metal ions dissolved in seawater in proportion to
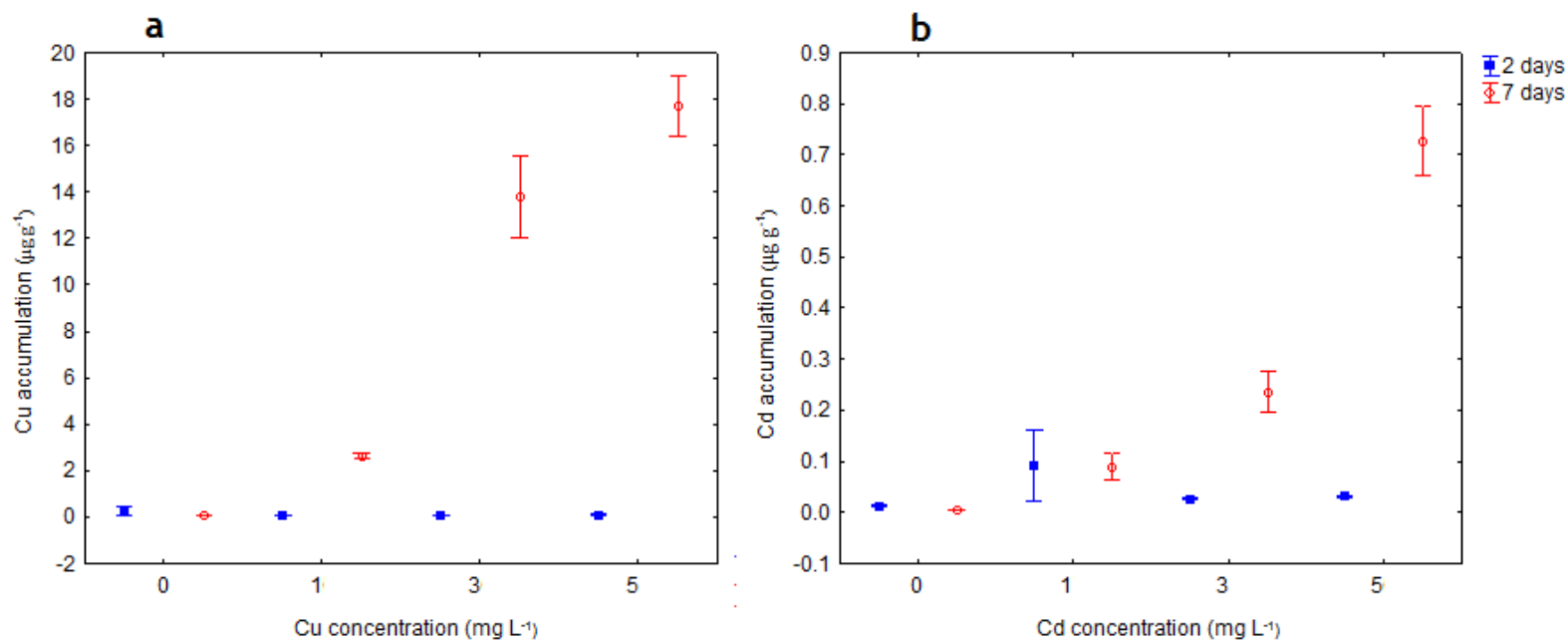

\section{Figure 5}

Bioaccumulation of copper (a) and cadmium (b) in the macroalga U. reticulata. Algae were exposed to heavy metals for 2 and 7 days at three concentrations. Error bars indicate SE of mean values $(n=3)$ 
their concentration (Wang et al. 2014; Seepersaud et al. 2018). The bioaccumulation capacity of $U$. reticulata indicated that this alga could be used as an indicator species to assess metal pollution in coastal zones. A good bioindicator of metal pollution should show a linear relationship between the concentration of metals in cells and in the environment (Phillips 1990). Previous laboratory studies also showed a strong linear correlation for metal concentration between thalli of Ulva species and culture tanks (Tabudravu et al. 2002; Chan et al. 2003). In seawater, however, environmental factors such as salinity, $\mathrm{pH}$ and nutrient content will affect the bioaccumulation process in macroalgae (Tabudravu et al. 2002). Therefore, it is important to consider physical and chemical factors of seawater when using Ulva species as a bioindicator of metal pollution (Rybak et al. 2012).

The results indicated a decrease in chlorophyll- $a$ and carotenoid content in algal samples treated with copper and cadmium for 2 days. While the Chl- $a$ and carotenoid levels decreased, the differences between control and metal-treated algal samples were not statistically significant. In a similar study, the Chl- $a$ content in the red alga Sarcodia suiae was reduced by the cadmium treatment (Han et al. 2020). Another alga, Gracilaria domingensis, showed a decrease in Chl- $a$ content after exposure to cadmium for 4 days (Dos Santos et al. 2012). Another study by Ji et al. (2018) also indicated that cadmium pollution affects photosynthesis of the alga Phaeodactylum tricornutum. On the other hand, a study by Pinto et al. (2011) reported an increase in Chl- $a$ and carotenoid content in the marine alga Gracilaria tenuistipitata exposed to copper and cadmium for $24 \mathrm{~h}$. Similarly, an increase in carotenoid content was observed in this study in samples treated with cadmium for 7 days. This indicates that physiological effects of heavy metals depend mainly on the exposure duration. In general, higher levels of metals in water may inhibit photosynthesis, reduce concentration of pigments and affect the growth of macroalgae (Xia et al. 2004; Contreras et al. 2007).The increase in photosynthetic pigments in algal samples treated with cadmium may be one of the defense mechanisms against toxicant stress (Ramlov et al. 2014).

Most algae species adapt easily to metal pollution through various physiological mechanisms (Contreras-Porcia et al. 2017). The resistance mechanisms against heavy metal toxicity are mainly involved in the production of polyphenols, which act as chelating agents (Toth \& Pavia 2000). In general, phenolics prevent the catalytic functions of metals by acting as metal chelators (Wu \& Hansen 2008). The results of the present study indicate that the total phenol content was reduced in algal samples treated with copper, while it showed higher values (after 2 days) in samples treated with cadmium. Further, algal samples treated with copper and cadmium showed an increase in antioxidant capacity. As antioxidant activity is directly related to the total phenolic content (Zhang et al. 2007), the increase in total antioxidant capacity in this study may be a resistance strategy of $U$. reticulata to the metal toxicity.

In this study, antifouling mechanisms of $U$. reticulata were tested against two fouling bacteria strains isolated from artificial substrates. The bacterial growth inhibitory activity in algal samples was reduced after exposure to copper and cadmium (except a slight increase in the algal sample treated with $5 \mathrm{mg} \mathrm{l}^{-1}$ of copper for 7 days). The increase in bacterial growth was observed even after an increase in total antioxidant capacity and total phenolic content of algal samples treated with the metals. Phenolic compounds are the major group of secondary metabolites used by algae against pathogens, grazers and biofouling organisms (Da Gama et al. 2014). Therefore, the reduction in bacterial growth inhibitory activity may be due to algae prioritizing the use of available resources to mitigate the toxic effects of metals. On the other hand, chemical defense is an energy consuming process (Nylund et al. 2013) and the reduction in photosynthesis may further reduce the energy reserves of algae. The decrease in energy content affects the production of secondary metabolites that are important for chemical defense (Ramalhosa et al. 2016).

Macroalgae exhibit constitutive (permanent) and induced (temporary) chemical defenses as protective mechanisms against attacks of herbivores and fouling organisms (Cronin \& Hay 1996). The induced chemical defense involves increased production of secondary metabolites due to grazing or other competitors. Therefore, the induced defense trait may be more sensitive to abiotic and biotic factors. In a previous study, Warneke \& Long (2015) reported that copper contamination reduced the inducible defense in the marine alga Silvetia compressa. Moreover, it has been reported that environmental stressors change the defense traits of seaweeds against herbivores (Yates \& Peckol 1993; Warneke \& Long 2015). The results observed in this study indicate possible indirect effects of metal pollution on macroalgal communities in coastal ecosystems. Specifically, an increase in heavy metal pollutants may change the structure of macroalgal assemblages and thus affect the ecosystem services. In addition to the reduction in photosynthetic pigments, results of this study study revealed that those macroalgae inhabiting the high 
metal-contaminated regions may have weak defense traits against epibiosis and herbivores.

Of the two metals used in this study, copper is considered an essential trace element for physiological functions of macroalgae (Leal et al. 2018). However, higher concentrations of copper in seawater are reported to have toxic effects on macroalgal communities and other aquatic organisms (Kramer \& Clemens 2006; Gouveia et al. 2013). The significant negative correlation between copper accumulation in algal samples and $\mathrm{Chl}-a$, total phenolic content and growth of the bacteria $P$. shioyasakiensis indicate direct effects of this metal on $U$. reticulata. The negative correlation with the growth of $P$. shioyasakiensis may be due to the antifouling activity of copper. Copper-based compounds are commonly used as a booster biocide in antifouling paints (Fay et al. 2019). On the other hand, the positive correlation between the copper content in algae and the growth rate of $V$. harveyi indicates that the effect of copper on microbial communities is species-specific. Unlike copper, cadmium is not an essential element for macroalgae and represents a potential threat to human health due to accumulation in the food chain (Volesky \& Holan 1995; Webster et al. 1997). Cadmium can also seriously affect phytoplankton and macroalgae in marine ecosystems (Payne \& Price 1999; Kapkow et al. 2011).

In this study, statistically significant differences were observed between the effects of two metals on total antioxidant capacity and total phenolic content of algal samples, with higher phenolic content found in samples treated with cadmium. It has been reported that phenols are secondary metabolites of algae responsible for the antioxidant activity (Ganesan et al. 2008; Pereira et al. 2017). Antioxidant compounds protect algae from the production of reactive oxygen species (ROS) by acting as free radical scavengers (Kokilam \& Vasuki 2014). In a previous study, the correlation between stress tolerance and higher levels of antioxidants were observed in brown algae from the genus Fucus (Collen \& Davidson 1999). Ahmad et al. (2010) reported that phenolic compounds are non-enzymatic antioxidants that usually act as terminators and chelators for free radical chains and redox-active metal ions capable of inducing lipid peroxidation. Although algal samples treated with cadmium showed higher phenolic content after 2 days, further treatment with this metal resulted in reduced total phenolic content. This indicates that the effect of cadmium on the antioxidant defense mechanism of algae may be stronger than that of copper.

In conclusion, the results of the present study indicate that exposure of $U$. reticulata to copper and cadmium induced protective mechanisms against metal stress but reduced photosynthesis. Furthermore, exposure to metals reduced the algal defense against marine biofilm-forming bacteria. Although the results showed bioaccumulation in algal samples exposed to higher concentrations of metals, changes in physiological parameters and antifouling defense were observed even for algae treated with a low concentration of metals for a short period of time ( 2 days). Further studies using different macroalgae species (instead of a single species) may be helpful in understanding the antifouling response of other algae species to heavy metal pollution. Comparison of defense traits observed in laboratory studies with macroalgal samples collected from presumably polluted sites will also provide more information on physiological and antifouling responses of macroalgal communities to anthropogenic stressors.

\section{Acknowledgements}

We thank the Faculty of Marine Sciences, King Abdulaziz University for providing necessary facilities.

\section{References}

Ahmad, P., Jaleel, C.A., Salem, M.A., Nabi, G. \& Sharma, S. (2010). Roles of enzymatic and nonenzymatic antioxidants in plants during abiotic stress. Crit. Rev. Biotechnol. 30: 161-175. DOI: 10.3109/07388550903524243.

Alsaafani, M.A., Alraddadi, T.M. \& Albarakati, A.M. (2017). Seasonal variability of hydrographic structure in Sharm Obhur and water exchange with the Red Sea. Arab. J. Geosci. 10: 315. DOI: 10.1007/s12517-017-3108-8.

Balqadi, A.A., Salama, A.J. \& Satheesh, S. (2018). Microfouling development on artificial substrates deployed in the central Red Sea. Oceanologia 60: 219-231. DOI: 10.1016/j. oceano.2017.10.006.

Brodie, J., Maggs, C.A. \& John, D.M. (2007). Green seaweeds of Britain and Ireland. pp. [i-v], vi-xii, 1-242, 101 figs. London: British Phycological Society.

Chan, S.M., Wang, W. \& Ni, I. (2003). The uptake of Cd, Cr, and Zn by the macroalga Enteromorpha crinita and subsequent transfer to the marine herbivorous rabbitfish, Siganus canaliculatus. Arch. Environ. Contam. Toxicol. 44: 298-306.

Collen, J. \& Davison, I.R. (1999). Reactive oxygen production and damage in intertidal Fucus spp. (Phaeophyceae). J. Phycol. 35: 54-61. DOI: 10.1046/j.1529-8817.1999.3510054.x.

Contreras, L., Medina, M.H., Andrade, S., Oppliger, V. \& Correa, J.A. (2007). Effects of copper on early developmental stages of Lessonia nigrescens Bory (Phaeophyceae). Environ. Pollut. 145: 75-83. DOI: 10.1016/j.envpol.2006.03.051. 
Contreras, L., Mella, D., Moenne, A. \& Correa, J.A. (2009). Differential responses to copper-induced oxidative stress in the marine macroalgae Lessonia nigrescens and Scytosiphon lomentaria (Phaeophyceae)

Contreras-Porcia, L., Meynard, A., López-Cristoffanini, C., Latorre, N. \& Kumar, M. (2017). Marine metal pollution and effects on seaweed species. In M. Kumar \& P. Ralph (Eds.), Systems Biology of Marine Ecosystems (pp. 35-48). Cham: Springer. DOI: 10.1007/978-3-319-62094-7_3.

Cronin, G. \& Hay, M.E. (1996). Induction of seaweed chemical defenses by amphipod grazing. Ecology 77: 287-301. DOI: $10.2307 / 2265731$.

da Costa, C.H., Perreault, F., Oukarroum, A., Melegari, S.P., Popovic, R. et al. (2016). Effect of chromium oxide (III) nanoparticles on the production of reactive oxygen species and photosystem II activity in the green alga Chlamydomonas reinhardtii. Sci. Total Environ. 565: 951960. DOI: 10.1016/j.scitotenv.2016.01.028.

Da Gama, B.A.P., Plouguerné. E. \& Pereira, R.C. (2014). The antifouling defence mechanisms of marine macroalgae. Adv. Bot. Res. 71: 413-440. DOI: 10.1016/B978-0-12408062-1.00014-7.

Da Gama, B.A.P., Santos, R.P.A. \& Pereira, R.C. (2008). The effect of epibiosis on the susceptibility of the red seaweed Cryptonemia seminervis to herbivory and fouling. Biofouling 24: 209-218. DOI: 10.1080/08927010802041253.

Dhargalkar, V.K. \& Kavlekar, D.P. (2004). Seaweeds-a field manual (pp. 36). National Institute of Oceanography, Goa, India.

Dos Santos, R.W., Schmidt, E.C., Martins, R.P., Latini, A., Maraschin, M. et al. (2012). Effects of cadmium on growth, photosynthetic pigments, photosynthetic performance, biochemical parameters and structure of chloroplasts in the Agarophyte Gracilaria domingensis (Rhodophyta, Gracilariales). Am. J. Plant Sci. 3: 1077-1084. DOI: 10.4236/ ajps.2012.38129.

Faÿ, F., Gouessan, M., Linossier, I. \& Réhel, K. (2019). Additives for efficient biodegradable antifouling paints. Int. J. Mol. Sci. 20: 361. DOI: 10.3390/ijms20020361.

Flouty, R. \& Estephane, G. (2012). Bioaccumulation and biosorption of copper and lead by a unicellular algae Chlamydomonas reinhardtii in single and binary metal systems: A comparative study. J. Environ. Manage. 111: 106-114. DOI: 10.1016/j.jenvman.2012.06.042.

Foyer, C.\& Noctor, G. (2011). Ascorbate and glutathione: The heart of the redox hub. Plant Physiol. 155: 2-8. DOI: 10.1104/pp.110.167569.

Fu, C.W.F., Ho, C.W., Yong, W.T.L., Abas, F. \&Tan, C.P. (2015). Effects of phenolic antioxidants extraction from four selected seaweeds obtained from Sabah. PeerJ 3: p.e1249v1. DOI: 10.7287/peerj.preprints.1249v1.

Ganesan, P., Kumar, C.S. \& Bhaskar, N. (2008). Antioxidant properties of methanol extract and its solvent fractions obtained from selected Indian red seaweeds.
Bioresour. Technol. 99: 2717-2723. DOI: 10.1016/j. biortech.2007.07.005.

Gouveia, C., Kreusch, M., Schmidt, É.C., Marthiellen, R.D.L., Osorio, L.K. et al. (2013). The effects of lead and copper on the cellular architecture and metabolism of the red alga Gracilaria domingensis. Microsc. Microanal. Microstruct. 19: 513-524. DOI: 10.1017/S1431927613000317.

Gressler, V., Fujii, M.T., Martins, A.P., Colepicolo, P. \& Pinto, P. (2011). Biochemical composition of two seaweed species grown on the Brazilian coast. J. Sci. Food Agric. 91: 1687-92. DOI: 10.1002/jsfa.4370.

Han, T.W., Tseng, C.C., Cai, M., Chen, K., Cheng, S.Y. et al. (2020). Effects of cadmium on bioaccumulation, bioabsorption, and photosynthesis in Sarcodia suiae. Int. J. Environ. Res. Public Health 17: 1294. DOI: 10.3390/ijerph17041294.

Huang, X., Ke, C. \& Wang, W.X. (2010). Cadmium and copper accumulation and toxicity in the macroalga Gracilaria tenuistipitata. Aquat. Biol. 11: 17-26. DOI: 10.3354/ ab00288.

Ismail, G.A. \& Ismail, M.M. (2017). Variation in oxidative stress indices of two green seaweeds growing under different heavy metal stresses. Environ. Monit. Assess. 189: 68. DOI: 10.1007/s10661-017-5775-z.

Jeffrey, S.T. \& Humphrey, G.F. (1975). New spectrophotometric equations for determining chlorophylls $a, b, c 1$ and $c 2$ in higher plants, algae and natural phytoplankton. Biochem. Physiol. Pflanz. 167: 191-194.

Ji, Y., Xie, X.J. \& Wang, G.G. (2018). Effects of the heavy metal cadmium on photosynthetic activity and the xanthophylls cycle in Phaeodactylum tricornutum. J. Oceanol. Limnol. 36: 2194-2201. DOI: 10.1007/s00343-019-7160-y.

Jiang, H.P., Gao, B.B., Li, W.H., Zhu, M., Zheng, C.F. et al. (2013). Physiological and biochemical responses of Ulva prolifera and Ulva linza to cadmium stress. Sci. World J. 2013: 289537. DOI: 10.1155/2013/289537.

Jormalainen, V. \& Honkanen, T. (2008). Macroalgal chemical defenses and their roles in structuring temperate marine communities. In C. Amsler (Ed.), Algal Chemical Ecology (pp. 57-89). Berlin: Springer. DOI: 10.1007/978-3-54074181-7_3.

Kapkov, V.I., Belenikina, O.A. \& Fedorov, V.D. (2011). Effect of heavy metals on marine phytoplankton. Mosc. Univ. Biol. Sci. Bull. 66: 32-36.

Kokilam, G. \& Vasuki, S. (2014). Biochemical and phytochemical analysis on Ulva fasciata and Caulerpa taxifolia. Int. J. Pharm. 4: 7-11.

Krämer, U. \& Clemens, S. (2006). Functions and homeostasis of zinc, copper, and nickel in plants. In M.J. Tamás \& E. Martinoia (Eds.), Molecular Bology of Metal Homeostasis and Detoxification from Microbes to Man (pp. 214-272). Berlin: Springer-Verlag. DOI: 10.1007/4735_96.

Leal, P.P., Hurd, C.L., Sander, S.G., Armstrong, E., Fernández, P.A. et al. (2018). Copper pollution exacerbates the effects of ocean acidification and warming on kelp microscopic 
early life stages. Sci. Rep. 8: 1-13. DOI: 10.1038/s41598018-32899-w.

Lozano-Bilbao, E., Díaz, Y., Lozano, G., Jurado-Ruzafa, A., Hardisson, A. et al. (2019). Metal content in small pelagic fish in the north-west Africa. Thalassas 35: 643-653. DOI: 10.1007/s41208-019-00141-7.

Lürling, M.F.L.L.W. (2012). Infodisruption: pollutants interfering with the natural chemical information conveyance in aquatic systems. In C. Brönmark \& L.A. Hansson (Eds.), Chemical Ecology in Aquatic Systems (pp. 250-271). Oxford university press. DOI: 10.1093/acprof:o sobl/9780199583096.001.0001.

Mannino, A.M. \& Micheli, C. (2020) Ecological function of phenolic compounds from Mediterranean fucoid algae and seagrasses: An overview on the genus Cystoseira sensu lato and Posidonia oceanica (L.). J. Mar. Sci. Eng. 8: 19. DOI: 10.3390/jmse8010019.

Martins, C.D., Arantes, N., Faveri, C., Batista, M.B., Oliveira, E.C. et al. (2012). The impact of coastal urbanization on the structure of phytobenthic communities in southern Brazil. Mar. Pollut. Bull. 64: 772-778. DOI: 10.1016/j. marpolbul.2012.01.031.

Nylund, G.M., Enge, S. \& Pavia, H. (2013). Costs and benefits of chemical defence in the red alga Bonnemaisonia hamifera. PloS one 8: e61291 . DOI: 10.1371/journal.pone.0061291.

Ozsoy, N., Can, A., Yanardag, R. \& Akev, N. (2008). Antioxidant activity of Smilax excelsa L. leaf extracts. Food Chem. 110: 571-583.

Paul, V.J., Cruz-Rivera, E. \& Thacker, R.W. (2001). Chemical mediation of macroalgal-herbivore interactions: ecological and evolutionary perspectives. In J.B. McClintock \& B.J. Baker (Eds.), Marine Chemical Ecology (pp. 227-265). Boca Raton, Florida: CRC Press.

Paul, V.J., Puglisi, M.P. \& Ritson-Williams, R. (2006). Marine chemical ecology. Nat. Prod. 23: 153-180.

Payne, C.D. \& Price, N.M. (1999). Effects of cadmium toxicity on growth and elemental composition of marine phytoplankton. J. Phycol. 35: 293-302.

Pereira, D.T., Simioni, C., Filipin, E.P., Bouvie, F., Ramlov, F. et al. (2017). Effects of salinity on the physiology of the red macroalga, Acanthophora spicifera (Rhodophyta, Ceramiales).ActaBot.Bras.31:555-565. DOI: 10.1590/0102$33062017 \mathrm{abb} 0059$.

Pereira, R.C. \& Da Gama, B.A.P. (2008). Macroalgal chemical defenses and their roles in structuring tropical marine communities. In C. Amsler (Ed.), Algal Chemical Ecology (pp. 25-55). Berlin: Springer.

Phillips, D.J.H. (1990). Use of macroalgae and invertebrates as monitors of metal levels in estuaries and coastal waters. In R.W. Furness \& P.S. Rainbow (Eds.), Heavy Metals in the Marine Environment (pp. 81-99). Florida: CRC Press.

Pinto, E., Carvalho, A.P., Cardozo, K.H.M., Malcata, F.X., Anjos, F.M.D. et al. (2011). Effects of heavy metals and light levels on the biosynthesis of carotenoids and fatty acids in the macroalgae Gracilaria tenuistipitata (var. liui Zhang \& Xia). Rev. Bras. Farmacogn. 21: 349-354. DOI: 10.1590/S0102695X2011005000060.

Pise, N.M., Gaikwad, D.K. \& Jagtap, T.G. (2013). Oxidative stress and antioxidant indices of the marine red alga Porphyra vietnamensis. Acta Bot. Croat. 72: 197-209.

Polo, L.K., De, L., Felix, M.R., Kreusch, M., Pereira, D.T. et al. (2014). Photoacclimation responses of the brown macroalga Sargassum cymosum to the combined influence of UV radiation and salinity: cytochemical and ultrastructural organization and photosynthetic performance. Photochem. Photobiol. 90: 560-573. DOI: 10.1111/php.12224.

Prieto, P., Pineda, M. \& Aguilar, M. (1999). Spectrophotometric quantification of antioxidant capacity through the formation of a phosphomolybdenum complex: specific application to the determination of vitamin E. Anal. Biochem. 269: 337-341.

Ramalhosa, P., Debus, S.L., Kaufmann, M. \& Lenz, M. (2017). A non-native macroalga is less attractive for herbivores but more susceptible to light limitation and grazing stress than a comparable native species. Helgol. Mar. Res. 70: 25. DOI: 10.1186/s10152-016-0478-3.

Ramlov, F., Carvalho, T.J.G., Schmidt, É.C., Martins, C.D.L., Kreusch, M.G. et al. (2014). Metabolic and cellular alterations induced by diesel oil in Hypnea musciformis (Wulfen) JV Lamour.(Gigartinales, Rhodophyta). J. Appl. Phycol. 26: 1879-1888.

Rybak, A., Messyasz, B. \& Łęska, B. (2012). Freshwater Ulva (Chlorophyta) as a bioaccumulator of selected heavy metals $(\mathrm{Cd}, \mathrm{Ni}$ and $\mathrm{Pb}$ ) and alkaline earth metals ( $\mathrm{Ca}$ and Mg). Chemosphere 89: 1066-1076. DOI: 10.1016/j. chemosphere.2012.05.071.

Sáez, C.A., Lobos, M.G., Macaya, E.C., Oliva, D., Quiroz, W. et al. (2012). Variation in patterns of metal accumulation in thallus parts of Lessonia trabeculata (Laminariales; Phaeophyceae): implications for biomonitoring. PloS one 7: e50170. DOI: 10.1371/journal.pone.0050170.

Salama, A.J., Satheesh, S. \& Balqadi, A.A. (2018). Development of Biofouling Communities on Nylon Net Panels Submerged in the Central Red Sea: Effects of Season and Depth. Thalassas 34: 199-208. DOI: 10.1007/s41208-0170052-z.

Saleh, B. (2015). Physiological response of the green algae Ulva lactuca (Chlorophyta) to heavy metals stress. J. Stress Physiol. 11: 38-51.

Scherner, F., Horta, P.A., de Oliveira, E.C., Simonassi, J.C., HallSpencer, J.M. et al. (2013). Coastal urbanization leads to remarkable seaweed species loss and community shifts along the SW Atlantic. Mar. Pollut. Bull. 76: 106-115. DOI: 10.1016/j.marpolbul.2013.09.017.

Schiel, D.R. \& Foster, M.S. (2015). The biology and ecology of giant kelp forests (First edition) p 416. Oakland, CA: University of California Press. 
Seepersaud, M.A., Ramkissoon, A., Seecharan, S., PowderGeorge, Y.L. \& Mohammed, F.K. (2018). Environmental monitoring of heavy metals and polycyclic aromatic hydrocarbons (PAHs) in Sargassum filipendula and Sargassum vulgare along the eastern coastal waters of Trinidad and Tobago, West Indies. J. Appl. Phycol. 30: 21432154. DOI: 10.1007/s10811-017-1372-3.

Singleton, V.L. \& Rossi, J.A. (1965). Colorimetry of total phenolics with phosphomolybdic-phosphotungstic acid reagents. Am. J. Enol. Viticult. 16: 144-158.

Sudatti, D.B., Fujii, M.T., Rodrigues, S.V., Turra, A. \& Pereira, R.C. (2018). Prompt induction of chemical defenses in the red seaweed Laurencia dendroidea: The role of herbivory and epibiosis. J. Sea Res. 138: 48-55. DOI: 10.1016/j. seares.2018.04.007.

Tabudravu, J.N., Gangaiya, P., Sotheeswaran, S. \& South, G.R. (2002). Enteromorpha flexuosa (Wulfen) J. Agardh (Chlorophyta: Ulvales) - evaluation as an indicator of heavy metal contamination in a tropical estuary. Environ. Monit. Assess. 75: 201-213.

Topcuoglu, S., Ergül, H.A., Baysal, A., Ölmez, E. \& Kut, D. (2003). Determination of radionuclide and heavy metal concentrations in biota and sediment samples from Pazar and Rize stations in the eastern Black Sea. Fresen Environ. Bull. 12: 695-699.

Torres, P.B., Chow, F., Furlan, C.M., Mandelli, F., Mercadante, A. et al. (2014). Standardization of a protocol to extract and analyze chlorophyll a and carotenoids in Gracilaria tenuistipitata Var. Liui. Zhang and Xia (Rhodophyta). Brazilian J. Oceanogr. 62: 57-63.

Toth, G. \& Pavia, H. (2000). Lack of phlorotannin induction in the brown seaweed Ascophyllum nodosum in response to increased copper concentrations. Mar. Ecol. Prog. Ser. 192: 119-126.

Tzafriri-Milo, R., Benaltabet, T., Torfstein, A. \& Shenkar, N. (2019). The potential use of invasive ascidians for biomonitoring heavy metal pollution. Front Mar. Sci. 6: 611. DOI: 10.3389/ fmars.2019.00611.

Tzure-Meng, W.U., Yi-Ting, H.S.U. \& Tse-Min, L.E.E. (2009). Effects of cadmium on the regulation of antioxidant enzyme activity, gene expression, and antioxidant defenses in the marine macroalga Ulva fasciata. Bot. Stud. 50: 25-34.

Volesky, B. \& Holan, Z.R. (1995). Biosorption of heavy metals. Biotechnol. Prog. 11: 235-250.

Wang, Z., Wang, X. \& Ke, C. (2014). Bioaccumulation of trace metals by the live macroalga Gracilaria lemaneiformis. J. Appl. Phycol. 26: 1889-1897. DOI: 10.1007/s10811-0130222-1.

Warneke, A.M. \& Long, J.D. (2015). Copper contamination impairs herbivore initiation of seaweed inducible defenses and decreases their effectiveness. PloS one 10: e0135395. .DOI: 10.1371/journal.pone.0135395.

Webster, E.A., Murphy, A.J., Chudek, J.A. \& Gadd, G.M. (1997). Metabolism-independent binding of toxic metals by Ulva lactuca: cadmium binds to oxygen-containing groups, as determined by NMR. BioMetals 10: 105-117.

Wu, X.J. \& Hansen, C. (2008). Antioxidant capacity, phenolic content, polysaccharide content of Lentinus edodes grown in whey permeate based submerged culture. J. Food Sci. 73: M1-M8.

Xia, J.R., Li, Y.J., Lu, J. \& Chen, B. (2004). Effects of copper and cadmium on growth, photosynthesis. Bull. Environ. Contam. Toxicol. 73: 979-986.

Yadav, S. (2010). Heavy metal toxicity in plants: An overview on the role of glutathione and phytochelatins in heavy metal stress in plants. S. Afr. J. Bot. 76: 167-179. DOI: 10.1016/j. sajb.2009.10.007.

Yates, J.L. \& Peckol, P. (1993). Effects of nutrient availability and herbivory on polyphenolics in the seaweed Fucus. Ecology 74: 1757-1766.

Zhang, W., Duan, X., Huang, H., Zhang, Y. \& Wang, B. (2007). Evaluation of 28 marine algae from the Qingdao coast for antioxidative capacity and determination of antioxidant efficiency and total phenolic content of fractions and subfractions derived from Symphyocladia latiuscula (Rhodomelaceae). J. Appl. Phycol. 19: 97-108.

Zhu, X., Zou, D., Huang, Y., Cao, J., Sun, Y. et al. (2017). Physiological responses of Porphyra haitanensis (Rhodophyta) to copper and cadmium exposure. Bot. Mar. 60: 27-37. DOI: 10.1515/bot-2016-0117. 